\title{
Queda de Folíolos em Parkia pendula Causada por Pestalotiopsis sp. no Brasil
}

\author{
Regina C.T. Rosa \& Vanildo A. L. B. Cavalcanti \\ Laboratório de Fitossanidade e Controle Biológico da Empresa Pernambucana de Pesquisa Agropecuária (IPA), \\ Av. Gen. San Martin, 1371, Bonji, CEP 50761-000, Recife, PE
}

(Aceito para publicação em 05/09/2005)

Autor para correspondência: Vanildo A. L. B. Cavalcanti

\begin{abstract}
Pestalotiopsis sp. causing the fall of folioles in Parkia pendula in Brasil

This paper reports the occurrence of Pestalotiopsis sp. causing the fall of leaflets in visgueiro (Parkia pendula) seedlings in the State of Pernambuco, Brazil, in 2005. This is the first time that Pestalotiopsis sp. is reported in visgueiro in Brazil.
\end{abstract}

O visgueiro (Parkia pendula Benth) árvore da família Mimosaceae, ocorre em terra firme, nas matas primárias ou secundárias, na Região Amazônica, sul da Bahia, norte do Espírito Santo, Pernambuco e Alagoas. Sua madeira é utilizada na carpintaria e marcenaria, para caxotarias e outros. Usada para o plantio em áreas degradadas e de preservação permanente, graças ao seu rápido crescimento em ambientes abertos, e na arborização de praças públicas e parques (Lorenzi, Árvores Brasileiras: manual de identificação e cultivo de plantas arbóreas nativas do Brasil, 1992; Ribeiro et al., Flora da reserva Ducke: guia de identificação das plantas vasculares de uma floresta de terrafirme na Amazônia Central, 1999).

Mudas de visgueiro provenientes do município do Cabo de Santo Agostinho-PE foram enviadas ao Laboratório de Fitossanidade da Empresa Pernambucana de Pesquisa Agropecuária - IPA, apresentando manchas escuras nas bordas dos foliólulos que progrediam tornando-os escuros e secos com posterior queda do folíolo (Figura 1 A e B). O material foi analisado em microscópio esterioscópico e óptico, onde, após o preparo de lâminas, foram observados conídios do fungo pertencente ao gênero Pestalotiopsis. Foliólulos infetados foram submetidos à assepsia, em seguida transferidos para meio de cultura de BDA, onde se desenvolveu um fungo com micélio branco apresentando pontuações negras (Figura 1 C). Em lâminas semipermanentes observou-se conídios fusiformes, com quatro septos, células das extremidades hialinas e as medianas de coloração castanha, com um a três apêndices (Figura 1 D). Foram medidos 100 conídios que apresentaram 31,25 -
$18,75(25,04)$ x 6,25 - 3,81 $(5,64)$ ì m. Posteriormente, o fungo foi inoculado em mudas sadias de visgueiro, numa concentração de 1,75 x $10^{5}$ conídios. $\mathrm{ml}^{-1}$, e mantidos em câmara úmida durante 48 h, em condições de laboratório, na sede do IPA. Oito dias após, reisolou-se dos tecidos inoculados o mesmo fungo observado anteriormente, comprovando o postulado de Koch.

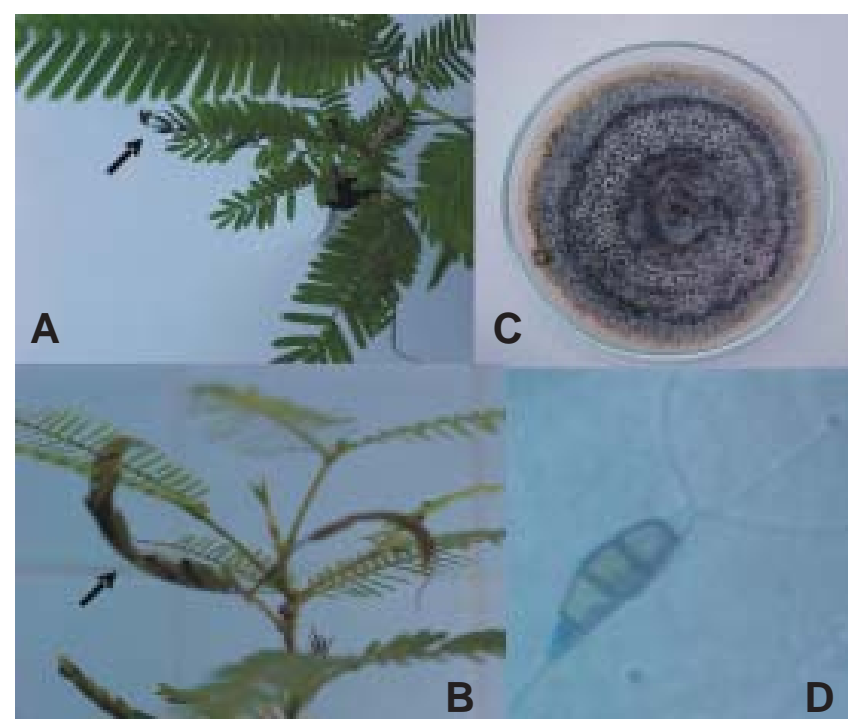

FIG. 1- Sintomas de queda de folíolos em visgueiro (Parkia pendula) causados por Pestalotiopsis sp. (A e B); colônia em meio BDA (C) e conídio do patógeno (D). 